\title{
PROBLEMATIKA PEMERINTAH DALAM MENYONGSONG BONUS DEMOGRAFI DI INDONESIA
}

\author{
Isyana Kurniasari Konoras \\ Institut Agama Islam Negeri Manado, Sulawesi Utara, Indonesia \\ Email: kurniasariisyana@gmail.com \\ Tria Anggraini Wagiran \\ Institut Agama Islam Negeri Manado, Sulawesi Utara, Indonesia \\ Email: wagirantria@gmail.com \\ Syaifullah Mukhlis \\ Institut Agama Islam Negeri Manado, Sulawesi Utara, Indonesia \\ Email: syaifullah.mukhlis@iain-manado.ac.id
}

\begin{abstract}
Demographic bonuses are a hot issue, although they are still limited to population and economic experts, even among other academics the term bonus demography is still not well known. The study has not reached a legal perspective.

Some aspects related to the demographic bonus are the implementation of the Sustainable Development Goals (SDGs) until 2030. While the prediction of achieving demographic bonuses by Indonesia in 2020-2030. The series of periods of achieving the demographic bonus, in the analysis of population experts including economists, still "shyly" mentions where the Republic of Indonesia and the Unitary State achieve their welfare. constitutional namely the welfare of society.
\end{abstract}

Keywords: Demographic Bonus, Sustainable Development, Legal Perspective, Unitary State of the Republic of Indonesia.

Abstrak. Bonus demografi menjadi isu hangat, meskipun masih sebatas di kalangan pakar kependudukan dan ekonomi, bahkan di kalangan akademisi lain istilah bonus demografi masih kurang akrab dikenal. Kajiannya pun belum sampai menyentuh perspektif hukum.

Beberapa aspek berkaitan dengan bonus demografi ialah implementasi tujuan Pembangunan Berkelanjutan (Sustainable Development Goals/SDGs) hingga tahun 2030. Sementara prediksi pencapaian bonus demografi oleh Indonesia di tahun 2020-2030. Rangkaian periodesasi pencapaian bonus demografi tersebut, pada analisis para pakar kependudukan termasuk para ekonom, masih "malu-malu" menyebutkannya di mana bangsa dan Negara Kesatuan Republik Indonesia mencapai kesejahteraannya, dalam arti kata melalui pencapaian bonus demografi, diharapkan bangsa dan Negara Indonesia dapat mewujudkan amanat konstitusional yakni mensejahterakan masyarakat.

Kata Kunci: Bonus Demografi, Pembangunan Berkelanjutan, Perspektif Hukum, Negara Kesatuan Republik Indonesia. 


\section{PENDAHULUAN}

Terminologi bonus demografi masih asing bagi warga masyarakat. Di kalangan akademisi pun banyak yang belum memahami apa dan bagaimana bonus demografi itu, serta apa urgensinya bagi Indonesia. Padahal, para pakar kependudukan memprediksi bahwa Indonesia akan mendapat bonus demografi pada tahun 2020-2030 mendatang, yakni jumlah penduduk usia produktif sangat besar sedangkan jumlah penduduk usia muda sangat kecil sementara jumlah penduduk lanjut usia belum banyak.

Besarnya proporsi penduduk usia produktif yakni yang berada pada rentang usia 15 tahun sampai 64 tahun dalam evolusi kependudukan tersebut, menyebabkan proporsi penduduk usia produktif menjadi modal penting dan berharga dalam mengemban kehidupan bermasyarakat, berbangsa, dan bernegara di Indonesia di masa mendatang. Namun, pendapaian bonus demografi tersebut bukanlah hal yang mudah, oleh karena keberhasilan pembangunan dari saat sekarang ini menentukan pencapaiannya. Permasalahan pokok yang dihadapi oleh Indonesia saat ini ialah masalah kemiskinan, kesenjangan pembangunan antar kawasan khususnya kawasan Indonesia bagian Barat dengan kawasan Indonesia bagian Timur, ketimpangan pendapatan, serta bencana alam yang berkepanjangan, dan lain sebagainya.

Masalah kemiskinan misalnya, dengan mengutip data Badan Pusat Statistik (BPS), Aunur Rofiq ${ }^{1}$,

\footnotetext{
${ }^{1}$ Aunur Rofiq, Pertumbuhan Ekonomi dan Kemiskinan. Kebijakan dan Tantangan Masa Depan, (Jakarta: Penerbit Republika, 2014), hlm. 68.
}

mengemukakan, menurut BPS, jumlah penduduk miskin per September 2012 mencapai 28,59 juta orang $(11,66$ persen), menurun dibanding Maret 2012 yang tercatat 29,13 juta orang $(11,95$ persen), atau terjadi penurunan sebesar 0,54 juta atau 540.000 orang. BPS pada bulan Maret 2015 mencatat jumlah orang miskin dalam rentang enam bulan, September 2014 - Maret 2015, bertambah 860.000 orang menjadi 28,59 juta jiwa atau 11,22 persen. Jumlah penduduk miskin yang terus bertambah tersebut merupakan peringatan penting untuk disikapi oleh pemerintah, mengingat konsep pengukuran kemiskinan berdasarkan jumlah penduduk miskin kronis (chronic poor) maupun menurut penduduk miskin sementara (transient poor) amat kabur, oleh karena masalah kemiskinan laksana es, yang tampak di permukaan justru lebih kecil dibandingkan yang terendam.

Dari perspektif hukum, berbagai peraturan perundang-undangan telah mengamanatkan perlindungan dan pemberdayaan terhadap penduduk miskin yang merupakan amanat konstitusional menurut Pembukaan Undang-undang Dasar Negara Republik Indonesia, yakni mewujudkan "kesejahteraan Umum". UU No. 11 Tahun 2009 tentang Kesejahteraan Sosial, misalnya pada pasal 19 menyatakan, penanggulangan kemiskinan merupakan kebijakan, program, dan kegiatan yang dilakukan terhadap orang, keluarga, kelompok dan atau/ masyarakat yang tidak mempunyai atau mempunyai sumber mata pencaharian dan tidak dapat memenuhi kebutuhan yang layak bagi kemanusiaan. Penekanan terhadap penanggulangan kemiskinan dalam ketentuan ini menjelaskan landasan 
hukum bagi Pemerintah yang lebih dituntut menjalankan kebijakan, program maupun kegiatan dalam penanggulangan kemiskinan sebagai bagian dari upaya pemenuhan kesejahteraan sosial.

Banyak peraturan perundangan yang mengatur upaya perlindungan dan pemberdayaan masyarakat dalam rangka pengentasan kemiskinan, tetapi sejauh ini masalah kemiskinan menjadi titik pusat kelemahan mendasar bagi Pemerintah, khususnya terkait dengan upaya pencapaian bonus demografi. Kemiskinan baik dari pendekatan garis kemiskinan maupun dibawah garis kemiskinan menunjukkan pekerjaan berat dalam tahun 2014-2015 yang ditandai dengan pelemahan perekonomian Indonesia di dalam bayang-bayang krisis seperti terjadi pada tahun 1997-1998, meningkatnya pemutusan hubungan kerja (PHK), ancaman kekeringan dan kebakaran hutan, lahan dan lain sebagainya.

Paralel dengan masalah kemiskinan tersebut diatas, dorongan menjadi Tenaga Kerja Indonesia (TKI) di luar negeri semakin meningkat baik sebagai TKI legal maupun illegal, meningkatnya tumpuan harapan untuk berusaha di sektor nonformal seperti penjadi pengojek di perkotaan, meningkatna angka kriminalitas dan lain sebagainya yang terkait erat dengan langkah instant untuk mempertahankan hidup dan kehidupan.

Kemiskinan menjadi akar sumber permasalahan Indonesia dalam mencapai bonus demografi, meskipun berbagai program pembangunan nasional semakin banyak berorientasi memberantas kemiskinan akan tetapi situasi dan kondisi kemiskinan sekarang ini yang makin meningkat, menjadi beban berat dalam upaya pencapaian bonus demografi mendatang. Modal dasar dan utama bagi Indonesia selain proses pembangunan telah dirancang dalam Sistem Perencanaan Pembangunan Nasional berdasarkan Undang-undang No. 25 Tahun 2004 serta Rencana Pembangunan Jangka Panjang Nasional Tahun 2005-2025 berdasarkan Undang-undang No. 17 Tahun 2007, serta dalam Rencana Pembangunan Jangka Menengah Nasional (RPJMN) yang disusun dan direncanakan dalam kurun waktu rezim berkuasa, maka aspek dan dampak yang bersifat international dapat berakibat terhadap rencana dan tujuan pembangunan di Indonesia.

Perubahan besar dan mendasar ialah kegiatan pembangunan nasional dihadapkan pada tataran implementatif yang membutuhkan modal besar guna membiayai berbagai program pembangunan yang berintikan kegiatan mengangkat taraf hidup rakyat yang lebih baik, maju dan bermartabat sebagaimana diamanatkan oleh konstitusi, antara lainnya terjadi pergeseran komitmen nasional dengan lebih mengedepankan berbagai komitmen international sebagai kerangka dan rujukannya. Tujuan Pembangunan Millenium (Millenium Development Goals (MDGs) adalah contoh komitmen international yang lebih diberikan penekanan dan perhatiannya. Pada Konferensi Tingkat Tinggi (KTT) Millenium Perserikatan Bangsa-Bangsa (PBB) bulan september 2000, sebanyak 189 negara anggota PBB yang sebagian besar diwakili oleh kepala pemerintahan sepakat untuk mengadopsi Deklarasi Millenium, yang berisikan pendekatan inklusif dan berpijak pada perhatian bagi pemenuhan hak-hak dasar manusia. Dalam konteks inilah, negara-negara 
anggota PBB kemudian mengadopsi Tujuan Pembangunan Millenium atau Millenium Development Goals (MDGs). Setiap tujuan (goal) memiliki satu atau beberapa target. Target yang tercakup dalam MDGs sangat beragam, mulai dari mengurangi kemiskinan, kelaparan, menuntaskan tingkat pendidikan dasar, mempromosikan kesamaan gender, mengurangi kematian anak dan ibu, mengatas HIV/AIDS dan berbagai penyakit lainnya, serta memastikan kelestarian lingkungan hidup dan membentuk kemitraan dalam pelaksanaan pembangunan. $^{2}$

MDGs dan beberapa tujuan serta targetnya, pada dasarnya sudah tercakup dan diatur dalam berbagai peraturan perundang-undangan. Penanggulangan kemiskinan dan kelaparan yang ditempatkan sebagai tujuan utama dan pertama dari MDGs telah diatur untuk diimplementasikan berdasarkan pada Undang-undang No. 11 Tahun 2009 tentang Kesejahteraan Sosial, Undang-Undang No. 13 Tahun 2011 tentang Penanganan Fakir Miskin, Undang-undang No. 19 Tahun 2013 tentang Perlindungan dan Pemberdayaan Petani, dan lain sebagainya. Tujuan MDGs lainnya yakni mendorong kesetaraan gender dan pemberdayaan perempuan, selain telah diamanatkan secara konstitusional sebagai bagian dari Hak Asasi Manusia (HAM), juga diatur dalam berbagai peraturan perundang-undangan antara lainnya dalam Undang-undang No. 23 Tahun 2004 tentang Penghapusan Kekerasan Dalam Rumah Tangga, Undang-undang No. 52 Tahun 2009 tentang Perkembangan Kependudukan

\footnotetext{
${ }^{2}$ Adi Fahrudin, Kesejahteraan Sosial International, (Bandung: Alfbeta, 2012), hlm. 28
}

dan Pembangunan Keluarga, Undangundang No. 35 Tahun 2014 tentang Perubahan atas Undang-Undang No. 23 Tahun 2002 tentang Perlindungan Anak, dan lain sebagainya. Menurut UndangUndang No. 52 Tahun 2009 disebutkan pada pasal 3 bahwa perkembangan kependudukan pembangunan keluarga berdasarkan prinsip pembangunan kependudukan yang terdiri atas keadilan dan kesetaraan gender. Ketentuan yang sama juga diatur dalam pasal 3 Undang-Undang No.23 Tahun 2004 tentang Penghapusan Kekerasan Dalam Rumah Tangga, bahwa penghapusan kekerasan dalam rumah tangga dilaksanakan berdasarkan atas keadilan dan kesetaraan gender.

Upaya pencapaian kesetaraan gender pada hakikatnya ditujukan untuk mencapai kesampai derajat, kedudukan, hak dan kewajiban serta peran di antara laki-laki dengan perempuan. Pencapaian kesetaraan gender diartikan sebagai suatu kesamaan, bukan sebagai perbedaan berdasarkan jenis kelamin dengan munculnya konsekuensi hukum baru sebagai akibatnya yakni pergeseran nilai-nilai konservatifkonvensional ke arah nilai-nilai kontemporer misalnya praktik perkawinan sejenis seperti yang dipersengketakan pada suatu lembaga peradilan di Provinsi Sulawesi Barat, dan praktik perkawinan sejenis di Provinsi Bali. Apabila kasus di Provinsi Sulawesi Barat lebih terkait pada pemalsuan identitas yakni pemalsuan terhadap keterangan jenis kelamin, maka kasus di Provinsi Bali merupakan bentuk perkawinan sejenis yang terungkap untuk pertama kali di Indonesia.

Pergeseran nilai-nilai kehidupan keluarga dan masyarakat, telah diprediksi oleh Isyana Kurniasari 
Konoras, bahwa putusan Mahkamah Konstitusi No. 46/ PUU-VII/2010, sarat dengan kepentingan HAM, yang belum sepenuhnya dapat diterima oleh semua elemen masyarakat, namun hal itu dapat dipahami sebagai bentuk penilakan terhadap berbagai isu HAM yang dapat terjadi dan berpengaruh baik dalam sistem hukum maupun dalam masyarakat Indonesia, misalnya perkawinan sejenin (perempuan dengan perempuan atau laki-laki dengan lakilaki), hanya dengan argumentasi hak kawin sejenis adalah HAM. ${ }^{3}$ Melarang perkawinan sejenis, akan diperkarakan sebagai bentuk pelanggaran HAM yang dijamin secara konstitusional berdasarkan Pasal 28D ayat (1) bahwa "setiap orang berhak atas pengakuan, jaminan, perlindungan, dan kepastian hukum yang adil serta perlakuan yang sama di hadapan hukum".

MDGs sama sekali tidak menaruh perhatian terhadap permasalahan hukum kontemporer seperti praktik kawin sejenis, namun konsep kesetaraan gender yang semua merupakan upaya untuk mensetarakan laki-laki dengan perempuan, dapat berakibat munculnya masalah baru seperti persoalan perkawinan sejenis dan isu-isu kontemporer laiinya. Dengan berakhirnya MDGs, maka era baru sebagai penerus MDGs ialah konsep Tujuan Pembangunan Berkelanjutan (Sustaineble Development Goals (SDGs) yang baru akan diadopsi pada tanggal 25-27 September 2015 oleh Majelis Umum PBB. Tujuan pembangunan Millenium (MDGs) yang dilanjutkan

\footnotetext{
${ }^{3}$ Isyana Kurniasari Konoras, Kajian Huku dan Hak Asasi Manusia Terhadap Anak Di Luar Nikah, (Tesis Program Pasca Sarjana Universitas Sam Ratulangi, Manado, 2013), hlm. 112.
}

dengan Tujuan Pembangunan Berkelanjutan (SDGs), akan lekat dengan konsep dan pemikiran Rachel Carsoa yang untuk pertama kalinya istilah sustainable development diperkenalkannya melalui bukunya "Silet Spring" yang terbit pertama kali pada tahun 1962. Dalam konsep pembangunan berkelanjutan (sustainable development) tersebut. Proses pembangunan atau perkembangan (development) diharapkan dapat memenuhi kebutuhan masa sekarang tanpa membahayakan kemampuan generasi yang akan datang untuk memenuhi kebutuhannya dalam memanfaatkan potensi sumber daya alam untuk kehidupan. ${ }^{4}$

MDGs dengan 8 (delapan) tujuannya merupakan kebijakan dan program pembangunan yang lebih realistis dan terukut. Pemeringkatan (Rating) dalam bentuk Indeks (index) seperti Indeks Kesetaraan dan Keadilan Gender Indonesia serta Indeks Kebahagiaan Indonesia dan lain-lainnya setiap tahun baik dengan indikator parsial maupun komposit didalam perkembangannya membutuhkan tambahan indikator baru seperti yang berkaitan dengan HAM. Pasca MDGs, hasil-hasil yang telah dicapai dan kendala yang dihadapi masih dapat diperjuangkan melalui SDGs yang baru akan diadopsi pada forum Agenda Pembangunan Berkelanjutan 2030. Berdasarkan hasil-hasil yang dicapai dalam MDGs, dalam tataran implementatif, besaran Dana Desa misalnya merupakan program

\footnotetext{
${ }^{4}$ Jimly Ashshiddiqie, Green Constitution: Nuansa Hijau Undang-Undang Dasar Negeri Republik Indonesia Tahun 1945, (Jakarta: RajaGrafindo Persada, 2009), hlm. 134.
} 
pembangunan yang dapat membantu mengentaskan kemiskinan di pedesaan.

\section{PEMBAHASAN}

\section{Kemiskinan Sebagai Kendala Utama Menyongsong Bonus Demografi}

Terpenuhinya kebutuhan pokok setiap orang menjadi bagian yang penting untuk menentukan tingkat kehidupannya, apakah berkecukupan, berlebihan, atau sebaliknya, tidak mampu mencukupinya. Mulyanto Sumardi dan Haas-Dieter Evers (ed.), mengemukakan, kebutuhan pokok atau kebutuhan dasar (basic human needs) dapat dijelaskan sebagai kebutuhan yang sangat penting guna kelangsungan hidup manusia, baik yang terdiri dari kebutuhan atau konsumsi individu (makan, perumahan, pakaian) maupun keperluan pelayanan sosial tertentu (air minum, sanitasi, transportasi, kesehatan, dan pendidikan). ${ }^{5}$

Kemiskinan merupakan kondisi tidak dapat dipenuhinya kebutuhan hidup setiap orang secara wajar. Sajogjo (dalam Soekartawi) mendefinisikan golongan miskin kalau pendapatannya kurang dari setara $420 \mathrm{~kg}$ beras untuk masyarakat perkotaan. ${ }^{6}$ Digunakannya beras sebagai patokan, oleh karena beras menjadi bahan makanan pokok masyarakat Indonesia. Soekartawi sendiri, mendefinisikan 'miskin' adalah bila ia mempunyai keterbatasan penghasilan, pemikiran, keterampilan, pendidikan, penghayatan kesusilaan,

\footnotetext{
5 Mulyanto Sumardi dan Haas-Dieter Evers (ed.), Kemiskinan dan Kebutuhan Pokok, (Jakarta: Rajawali, 1985), hlm. 2.

6 Soekartawi, Pembangunan Pertanian untuk Mengentas Kemiskinan, UI Press, Jakarta, 1996, hlm. 74-75.
}

penghayatan keagamaan, kesehatan, perumahan, hubungan sosial dalam keluarga, hubungan sosial dalam lingkungan sekitarnya, dan hubungan sosial dalam masyarakat yang lebih sosial. $^{7}$

Bappenas, 2002 (dalam Lincolin Arsyad), mendefiniskan kemiskinan sebagai suatu situasi atau kondisi yang dialami seseorang atau kelompok orang yang tidak mampu menyelenggarakan hidupnya sampai suatu taraf yang dianggap manusiasi. ${ }^{8}$ Lincolin Arsyad menjelaskan, masyarakat miskin selalu berada pada kondisi ketidakberdayaan atau ketidakmampuan mereka dalam hal memenuhi kebutuhan dasar, yaitu ketidakmampuan dalam (1) melakukan kegiatan usaha produktif; (2) menjangkau akses sumber daya sosialekonomi; (3) menentukan nasibnya sendiri dan senantiasa mendapatkan perlakuan diskriminatif; dan (4) membebaskan diri dari mental dan budaya miskin serta senantiasa mempunyai martabat dan harga diri yang rendah. ${ }^{9}$

Perserikatan Bangsa-Bangsa (PBB) dalam "The Millenium Report," mendefiniskan kemiskinan (poverty) sebagai "this minimum level and the poor constituted the actual number of people whose income or calorie intake are less than this"10 dijelaskan pula bahwa dengan terinspirasinya pendapat Amartya Sea, pemenang Hadiah Nobel tahun 1999, bahwa "The United Nations Development Programme (UNDP)

\footnotetext{
${ }^{7}$ Loc Cit.

${ }^{8}$ Lincolin Arsyad, Op Cit, hlm. 299.

${ }^{9}$ Lincolin Arsyad, Ibid, hlm. 302.

${ }^{10}$ United Nations, We the Peoples, The Role if the United Nations in the Twenty Century, (New York: The Millenium Report, 2001), p. 214.
} 
introduced measures for progress and for deprivation that focus on poverty from a human development perspective. It now views poverty as a denial of choices and opportunities for living a tolerable life. The human poverty index (HPI) constructed for each country provides a country by country picture of deprivation in terms longevity, education and economic factors."11

Masalah kemiskinan banyak dihadapi oleh negara-negara berkembang termasuk Negara Indonesia. Soekartawi mengemukakan, pada awal Pelita I jumlah pendidik miskin di Indonesia sekitar 70 juta jiwa atau sekitar 60 persen dari jumlah penduduk. Pada tahun 1990 jumlah tersebut tinggal 27 juta jiwa atau sekitar 15,1 persen dari jumlah penduduk. Hingga tahun 1993 jumlah penduduk miskin ini tinggal 23 juta jiwa atau sekitar 13,5 persen saja. ${ }^{12}$ Antara pertengahan tahun 1960-an sampai tahun 1996, waktu Indonesia berada dibawah kepemimpinan pemerintahan Orde Baru, Soeharto, tingkat kemiskinan di Indonesia menurun drastis baik di desa maupun di kota, karena pertumbuhan ekonomi yang cukup kuat dan adanya program-program penanggulangan kemiskinan yang efisien. Selama pemerintahan Soeharto, angka penduduk Indonesia yang tinggal di bawah garis kemiskinan menurun drastis, dari awalnya sekitar setengah dari jumlah keseluruhan populasi penduduk Indonesia, sampai sekitar 11 persen saja. Namun, ketika pada tahun 1990-an krisis finansial Asia terjadi, tingkat kemiskinan melejit tinggi, dari 11 persen menjadi 19,9 persen, yang

${ }^{11}$ Loc Cit.

${ }^{12}$ Soekartawi, Op Cit, hlm. 94. berarti prestasi yang sudah diraih Orde baru hancur seketika.

(http://www.indonesia-

investment.com/id/keuangan/angkaekonomi-makro/kemiskinan/item301).

Konsep kemiskinan berdasarkan tingkat pendapatan minimum adalah pembatas antara keadaan miskin dan tidak miskin yang lazim disebut sebagai garis batas kemiskinan. Konsep ini mengenal kemiskinan absolut yang merupakan keadaan atau kondisi di bawah garis kemiskinan oleh karena kebutuhan-kebutuhan pokok tidak dapat terpenuhi semuanya. Kemiskinan absolut atau di bawah garis kemiskinan berbeda dari kemiskinan relatif yang dimungkinkan dapat berubah keadaan atau kondisinya menjadi tidak miskin lagi.

Kemiskinan absolut dan kemiskinan relatif tersebut mudah berubah-ubah sehingga dibutuhkan niat dan kebijakan pemerintah yang populis, yang 'pro-poor' untuk mengangkat harkat dan martabatnya menjadi orang miskin (di bawah garis kemiskinan) atau kemiskinan absolut beranjak berada pada garis kemiskinan relatif, bahkan dapat lebih baik menjadi orang yang tidak miskin lagi. Kebijakan pemerintah yang bertujuan untuk mengentaskan kemiskinan misalnya pada rezim Orde Baru dengan berbagai Instruksi Presiden (Inpres) maupun Bantuan Presiden (Banpres) terbukti cukup mempercepat pengentasan kemiskinan, bahkan Inpres Desa Tertinggal (IDT) dapat menjadi bahan pembanding bagi kebijakan penyerapan Dana Desa sebagaimana dimaksud oleh UndangUndang No. 6 Tahun 2014, serta dengan berbagai kebijakan yang cenderung bersifat 'memaksa' Pemerintah Daerah Kabupaten/ Kota maupun Pemerintah Desa untuk menyerapkan Dana Desa 
dengan berbagai Peraturan Menteri dan Peraturan Bersama Menteri.

Perhatian besar dan kebijakankebijakan yang ditempuh oleh Pemerintah dalam mengentaskan kemiskinan merupakan hal penting, oleh karena kurangnya perhatian dan kebijakan seperti itu menyebabkan timbulnya kemiskinan struktural yakni jenis kemiskinan oleh karena kurang atau rendahnya perhatian aparatur pemerintahan baik di tingkat Pusat maupun di tingkat Daerah. Perhatian dan kebijakan yang menjadikan berbagai program pembangunan sebagai sarana pengentasan kemiskinan, juga telah menempatkan Pemerintah sebagai pihak yang mendorong dan melaksanakan pembangunan (developmentalist) yang akan senantiasa berseberangan dengan kalangan pecinta lingkungan hidup (enviromentalist) dalam kutub-kutub yang selalu berseberangan.

Prioritas

pembangunan infrastruktur yang berlangsung pesat dan cepat sekarang ini, telah menggerus kemampuan penduduk miskin bahkan meningkatkan jumlah penduduk dalam kategori kemikinan absolut, oleh karena tergusurnya lahan-lahan pertanian dan perkebunan baik untuk pembangunan real estate, pabrik-pabrik, jalan, jembatan, rel kereta api, sebagaimana tampak di Kabupaten Bekasi, Kabupaten Karawang dan lain sebagainya, yang menunjukkan fakta bahwa UndangUndang No. 41 Tahun 2009 tentang Perlindungan Lahan Pertanian Pangan Berkelanjutan menjadi contoh dari peraturan-peraturan perundangundangan yang mandul, tidak berdaya serta tidak bermanfaat. Pemerintah khususnya Pemerintah Daerah dengan kehendak kuat untuk menarik investor sebagai amanat Undang-Undang No. 25
Tahun 2007 tentang Investasi, telah berperan laksana 'hawkist' walaupun jelas dan tegas berakibat meningkatnya potensi penduduk miskin, seperti lahan pertaniannya yang berubah menjadi lahan kegiatan investor.

Pemerintah dan Pemerintah Daerah yang dengan gencar menarik investor, bahkan dengan dalih untuk mensejahterakan rakyat pada hakikatnya turut menggerogoti kekuatan ekonomi masyarakat, apalagi penduduk yang selama ini berada di bawah garis kemiskinan. Pihak investor pun 'menangkap' peluang besar ini sehingga pemerintah telah menjelma laksana burung elang yang cepat menyergap mangsanya (hawkist), juga dengan dalih kegiatan investasi di daerah pun menjadi sumber Pendapatan Asli Daerah (PAD). Siti Zuhro, juga mengemukakan bahwa hasil evaluasi Komite Pemantauan Pelaksanaan Otonomi Daerah (KPPOD) menunjukkan bahwa dari 1.379 Perda yang mengatur ketentuan pajak dan retribusi, sekurangkurangnya 31 persen diantaranya menghambat atau merusak iklim investasi di daerah. ${ }^{13}$ Data inilah menjadi fakta bahwa Peraturan Daerah (perda) pun dapat dibatalkan jika berisikan ketentuan yang menghambat dan/ atau merusak iklim investasi di daerah.

Anggaran Pendapatan dan Belanja Negara (APBN) dan Anggaran Pendapatan dan Belanja Daerah (APBD) masih kurang mengalokasikan anggaran bagi kepentingan, perlindungan, dan pemajuan penduduk miskin dengan berbagai konsekuensi misalnya

13 Siti Zuhro, Kisruh Peraturan Daerah: Mengurai Masalah dan Solusinya, (Yogyakarta: Penerbit Ombak, 2010), hlm. 5. 
rendahnya akses masyarakat miskin pada pelayanan kesehatan dan pendidikan dan lain sebagainya. Bagaimana penduduk miskin mau memeriksa dan mendapatkan pelayanan kesehatan secara murah namun bermanfaat, bagaimana penduduk miskin mampu menyekolahkan anakanaknya apabila biaya pendidikan yang begitu mahal. Bagaimana kualitas hidup penduduk miskin dapat dicapai menjadi lebih baik manakala tersumbatnya berbagai akses yang dapat menunjang kesejahteraannya.

Yenni Sucipto, dkk, ${ }^{14}$ mencatat banyak permasalahan ekonomi yang menyeruak ke permukaan, dan jika melihat kinerja pemerintahan lebih detail masih banyak aspek yang harus diperbaiki. Kondisi makro ekonomi Indonesia saat ini bisa disebut layaknya fatamorgana, yang menunjukkan keberhasilan yang indah namun ketika ditelisik lebih dalam tidak memiliki kekuatan untuk menggerakkan perekonomian pada jangka panjang. Tingginya pertumbuhan ekonomi tidak ada artinya jika sebagian besar masyarakat tidak memperoleh kesejahteraan, akibat makin tingginya kesenjangan pendapatan.

Kebanggaan yang sering diungkapkan bahwa Indonesia dengan Produk Domestik Bruto (PDB) yang makin besar, merupakan kekuatan ekonomi penting dalam menggerakkan perekonomian menuju kesejahteraan masyarakat, bangsa, dan negara, padahal ada sisi gelap yang dapat membahayakan untuk jangka menengah sampai janan panjang mendatang, yakni

14 Yenni Sucipto, dkk, APBN Konstitusional. Prinsip dan Pilihan Kebijakan, (Yogyakarta: GalangPress, 2014), hlm. 242. ketergantungan atas hutang luar negeri untuk membiayai berbagai proyek pembangunan. Direktur Utama PT. Bank BNI (Persero) Tbk, Baiquni yang hadir dalam penandatanganan pinjaman dari China Development Bank (CDB), mengatakan bahwa pinjaman dari CDB untuk membiayai infrastruktur di Indonesia total pembiayaan yang direncanakan mencapai USD 30 milliar (Harian Kontan, 17 September 2015, hlm. 12), membuktikan besarnya ketergantungan terhadap hutang luar negeri.

Besarnya angka kerjasama antara tiga bank BUMN dengan CDB tersebut menunjukkkan konsep yang digunakan ialah penyaluran dana (hutang) melalui saluran (channeling) melalui perbankan, tanpa dimasukkan kedalam postur anggaran APBN. Padahal, ketika kunjungan pimpinan IMF ke Indonesia, dengan lantang petinggi Indonesia menyuarakan sikap akan menolak bantuan (hutang) dari IMF. Penolakan bantuan seperti itu seakan-akan membayangkan ketegasan Presiden Soekarno yang dengan lantang mengatakan "Go to hell with your aid." Didiek J Rachbini mengemukakan, Indonesia terpaksa menjadi pengekspor modal ke negara-negara maju karena beban yang sudah sedemikian berat dengan outflow keluar yang negatif. Artinya, utang yang diperoleh tidak bisa menutupi kewajiban membayar utang yang jatuh tempo dan bunganya. ${ }^{15}$ Walt Whitman Rostow yang mengemukakan suatu negara bisa dikatakan siap tinggal landas (take-off) jika negara yang bersangkutan tidak lagi bergantung

15 Didiek J. Rachbini, Risiko Pembangunan yang Dibimbing Utang, (Jakarta: Gramedia Widiasarana Indonesia, 1995), hlm. 51. 
kepada utang luar negeri dalam anggaran belanja negara, investasi dan pengembangan ekonomi masyarakatnya. ${ }^{16}$ Merujuk pada teori lepas landas Rostow, maka jumlah penduduk miskin di Indonesia masih menjadi tantangan berat bagi pencapaian bonus demografi. Jika demikian, penduduk miskin inilah yang akan tertinggal di landa

\section{Bonus Demografi Dari Perspektif Hukum}

Dari perspektif hukum, penulis merumuskan bahwa bonus demografi merupakan seperangkat hukum yang mendukung transisi demografi guna mewujudkan masyarakat yang sejahtera. Berdasarkan rumusan ini, maka seperangkat hukum yang menunjang dan/ atau mendukung tercapainya bonus demografi dimulai dari ketentuan konstitusional kemudian dirinci dalam sejumlah peraturan perundangundangan yang berlaku di Indonesia, oleh karena bonus demografi dalam bahasan ini dimaksudkan dalam konteksnya di Negara Republik Indonesia.

Undang-Undang Dasar Negara Republik Indonesia Tahun 1945, pada pembukaannya, mengamanatkan tujuan nasional atau tujuan Negara Republik Indonesia yakni "untuk memajukan kesejahteraan umum, mencerdaskan kehidupan bangsa" adalah dua tujuan nasional atau tujuan Negara Republik Indonesia yang di dalamnya tercakup banyak peraturan perundang-undangan yang mendukung dan/ atau menunjang tercapainya tujuan tersebut antara lainnya tujuan nasional di bidang

\footnotetext{
${ }^{16}$ Ibid, hlm. 40.
}

pendidikan, yang menurut pasal 31 ayatayatnya Undang-Undang Dasar Negara Republik Indonesia Tahun 1945, disebutkan bahwa :

1) "Setiap warga negara berhak mendapatkan pendidikan.

2) Setiap warga negara wajib mengikuti pendidikan dasar dan pemerintah wajib membiayainya.

3) Pemerintah mengusahakan dan menyelenggarakan satu sistem pendidikan nasional, yang meningkatkan keimanan dan ketakwaan serta akhlak mulia dalam rangka mencerdaskan kehidupan bangsa, yang diatur dengan undang-undang.

4) Negara memprioritaskan anggaran pendidikan sekurang-kurangnya dua puluh persen dari anggaran pendapatan dan belanja negara serta anggaran pendapatan dan belanja daerah untuk memenuhi kebutuhan penyelenggaraan pendidikan nasional.

5) Pemerintahk memajukan ilmu pengetahuan dan teknologi dengan menjunjung tinggi nilai-nilai agama dan persatuan bangsa untuk kemajuan peradaban serta kesejahteraan umat manusia." Undang-Undang Dasar Negara Republik Indonesia Tahun 1945, dari perspektif HAM juga mengatur ketentuan konstitusional bidang pendidikanantara lainnya pada pasal 28C ayat (1), yang menyatakan bahwa "Setiap orang berhak mengembangkan diri melalui pemenuhan kebutuhan dasarnya, berhak mendapat pendidikan dan memperoleh manfaat dari ilmu 
pengetahuan dan teknologi, seni dan budaya, demi meningkatkan kualitas hidupnya dan demi kesejahteraan umat manusia."

Berdasarkan ketentuan pasal 31 ayat (3) Undang-Undang Dasar Negara Republik Indonesia, beberapa peraturan perundangan yang terkait erat dengan ketentuan konstitusional tersebut adalah Undang-Undang No. 20 Tahun 2003 tentang Sistem Pendidikan Nasional, dan Undang-Undang No. 39 Tahun 1999 tentang HAM. Menurut Undang-Undang No. 20 Tahun 2003, fungsi pendidikan nasional ditentukan dalam Pasal 3, Bahwa "Pendidikan Nasional berfungsi mengembangkan kemampuan dan membentuk watak serta peradaban bangsa yang bermartabat dalam rangka mencerdaskan kehidupan bangsa, bertujuan untuk berkembangnya potensi peserta didik agar menjadi manusia yang beriman dan bertakwa kepada Tuhan Yang Maha Esa, berakhlak mulia, sehat, berilmu, cakap, kreatif, mandiri, dan menjadi warga negara yang demokratis serta bertanggungjawab."

Undang-Undang No. 20

Tahun 2003 juga menentukan pada Pasal 6 ayat (1), bahwa "Setiap warga negara yang berusia tujuh sampai dengan lima belas tahun wajib mengikuti pendidikan dasar." Ketentuan ini pun belum mencapai dan menjangkau jenjang pendidikan selanjutnya sehingga perlu diperluas. Demikian pula dalam Undang-Undang No. 39 Tahun 1999 tentang HAM, terdapat beberapa ketentuan pendidikan dari perspektif HAM misalnya pada Pasal 12 yang berbunyi "Setiap orang berhak atas perlindungan bagi pengembangan pribadinya, untuk memperoleh pendidikan, mencerdaskan dirinya, dan meningkatkan kualitas hidupnya agar menjadi manusia yang beriman, bertakwa, bertanggungjawab, berakhlak mulia, bahagia, dan sejahtera sesuai dengan hak asasi manusia." Undang-Undang No. 39 Tahun 1999, juga menentukan Pasal 60 ayata (1), bahwa "Setiap anak berhak memperoleh pendidikan dan pengajaran dalam rangka pengembangan pribadi sesuai dengan minat, bakat, dan tingkatkan kecerdasannya."

Pendidikan sebagai upaya mencerdaskan kehidupan bangsa menjadi bagian penting dalam menilai dan mengukur kemampuan kualitas sumber daya manusia pada suatu negara. Pendidikan dasar adalah landasan atau modal berharga bagi setiap orang dalam hidup dan kehidupannya. Pada "The Millenium Report," PBB menyatakan, "Basic education is, and always has been, the key to freedom from subjugation, fear and want. Education is an effective weapon to fight poverty."17 Menurut Tulus T.H. Tambunan, tahun 1990, Bank Dunia lewat laporannya World Development Report on Poverty, mendeklarasikan bahwa suatu peperangan yang berhasil melawan kemiskinan perlu dilakukan secara serentak pada tiga front: (1) Pertumbuhan ekonomi yang luas dan padat karya yang menciptakan kesempatan kerja dan pendapatan bagi kelompok miskin; (2) Pengembangan Sumberdaya Manusia (Pendidikan, Kesehatan dan gizi) yang memberi mereka kemampuan lebih baik untuk memanfaatkan kesempatan kesempatan yang diciptakan oleh pertumbuhan ekonomi, dan (3) Membuat suatu

\footnotetext{
P. 111.
} 
jaringan pengaman sosial untuk mereka di antara penduduk miskin yang sama sekali tidak mampu mendapatkan keuntungan dari pertumbuhan ekonomi. ${ }^{18}$

Ketentuan lainnya yang terkait erat yang menunjang dan/ atau mendukung pencapaian bonus demografi ialah Undang-Undang No. 52 Tahun 2009 tentang Perkembangan Kependudukan dan Pembangunan Keluarga, yang pada Pasal 3 dinyatakan bahwa "Perkembangan Kependudukan dan pembangunan keluarga berdasarkan prinsip pembangunan kependudukan yang terdiri atas:

a. Kependudukan sebagai titik sentral kegiatan pembangunan;

b. Pengintegrasian kebijakan kependudukan ke dalam pembangunan sosial budaya, ekonomi, dan lingkungan hidup;

c. Partisipasi semua pihak dan gotong royong;

d. Perlindungan dan pemberdayaan terhadap keluarga sebagai unit terkecil dalam masyarakat;

e. Kesamaan hak dan kewajiban antara pendatang dan penduduk setempat;

f. Perlindungan terhadap budaya dan identitas penduduk lokal; dan

g. Keadilan dan kesetaraan gender." Dalam konteksnya di Indonesia, sejumlah peraturan dan kebijakan yang mendukung dan/ atau mendorong tercapainya bonus demografi, juga ditempuh dengan kebijakan yang bersifat memberikan perlindungan dan pemberdayaan. Konsep perlindungan

18 Tulus T.H. Tambunan, Perekonomian Indonesa. Beberapa Masalah Penting, (Jakarta: Ghalia Indonesa, 2003), hlm. 131. (hukum) secara tegas ditemukan dalam berbagai peraturan peraturan perundang-undangan, sedangkan konsep permberdayaan lebih banyak ditentukan dalam tataran kebijakan. Undang-Undang no. 20 Tahun 2008 tentang Usaha Mikro, Kecil, dan Menengah (UMKM), mengatur pemberdayaan yang dirumuskan pada Pasal 1 angka 8 bahwa "Pemberdayaan adalah upaya yang dilakukan Pemerintah, Pemerintah Daerah, Dunia Usaha, dan masyarakat secara sinergis dalam bentuk penumbuhan iklim dan pengembangan usaha terhadap usaha mikro, kecil, dan menengah sehingga mampu tumbuh dan berkembang menjadi usaha yang tangguh dan mandiri.

\section{Kesimpulan}

Problematika yang dihadapi oleh Pemerintah dalam menyongsong bonus demografi di Indonesia dapat dirinci sebagai berikut:

Pertama, rumusan tentang bonus demografi bonus yang dinikmati suatu negara sebagai akibat dari besarnya proporsi penduduk usia produktif (rentang usia 14 sampai 64 tahun) sebagai evolusi kependudukan, terjadi karena transisi demografi yang menyatakan bahwa perubahan yang terjadi terhadap tiga komponen utama pertumbuhan penduduk: kelahiran (fertilitas), kematian (mortalitas), dan perpindahan penduduk (mobilitas/migrasi), menyebabkan penduduk usia produktif lebih besar dibandingkan usia bayi dan anak-anak maupun lansia di atas 64 tahun. Besarnya proporsi penduduk usia produktif inilah yang menjadi modal dan sumber kekuatan bagi suatu negara yang mampu mencapainya. Namun, untuk mencapai bonus demografi, 
banyak permasalahan yang harus ditanggulangi, khususnya masalah kemiskinan, seperti juga merupakan permasalahan berat bagi Indonesia dalam mengatasinya. Berbagai kegiatan pembangunan nasional dalam Rencana Pembangunan Jangka Panjang Nasional (RPJPN), Rencana Pembangunan Jangka Menengah Nasional (RPJMN) maupun Rencana Pembangunan Jangka Menengah Daerah (RPJMD), berisikan sejumlah kegiatan pembangunan yang sebenarnya berpihak pada pencapaian kesejahteraan rakyat misalnya dalam bidang pendidikan, kesehatan, pertanian, kelautan dan perikanan, maupun pembangunan infrastruktur yang menunjang percepatan pencapaian kesejahteraan rakyat. Sealanjutnya, Penanggulangan kemiskinan dan kelaparan yang ditempatkan pada Tujuan Pembangunan Milenium pertama, hanya berlangsung dalam kurun waktu tahun 2000 sampai 2015, kemudian dilanjutkan dengan Tujuan Pembangunan Berkelanjutan dari tahun 2015 sampai tahun 2030.

$$
\text { Kedua, aspek pembiayaan }
$$
pembangunan nasional baik dalam rangka APBN, APBD, implementasi Tujuan Pembangunan Berkelanjutan yang membutuhkan biaya besar. Titik perhatian pemerintah dalam membangun infrastruktur seperti jalan, jalan tol, perkeretaapian, waduk, bandara, pelabuhan dan lain-lainnya yang sangat fantastis, tentunya patut mendapatkan perhatian. Yenny Sucipto, $\mathrm{dkk},{ }^{19}$ mengemukakan bahwa kebijakan APBN yang menjadikan utang luar negeri (ULN) sebagai penerimaan negara, sebenarnya ULN tidak layak

193. disebut penerimaan, karena penerimaan mengandalkan tanpa kewajiban membayar, sedangkan utang tetap harus dibayar. Bila ULN dimasukkan sebagai bagian dari mekanisme pembiayaan bukan pendapatan, sebenarnya yang terjadi adalah defisit anggaran terusmenerus.

Ketiga, aspek keikutsertaan Indonesia di forum PBB dalam rangka Tujuan Pembangunan Berkelanjutan, yang diwakili oleh Wakil Presiden, M. Jusuf Kalla, yang seharusnya diwakili dan dipimpin langsung oleh Presiden Indonesia, Jokowi, oleh karena hampir sebulan setelah penandatanganan Tujuan Pembangunan Berkelanjutan, Presiden Jokowi berkunjung ke Amerika Serikat. Dari aspek ketiga ini, Wakil Presiden yang memperkenalkan Kartu Indonesia Sehat (KIS) dan Kartu Indonesia Pintar), merupakan bagian penting dari pembuktian bahwa bidang kesehatan dan pendidikan menjadi titik perhatian dalam pembangunan manusia di Indonesia.

\section{DAFTAR PUSTAKA}

Adji Samekto, FX, Kapitalisme, Modernisasi dan Kerusakan Lingkungan, Genta Press, Yogyakarta, 2008

Ali, Achmad Menguak Teori Hukum (Legal Theory) dan Teori Peradilan (Judicialprudence) Termasuk Interpretasi UndangUndang (Legisprudence), Kencana, Jakarta, 2009

Arsyad, Lincolin, Ekonomi Pembangunan, Edisi 5, UPP STIM YKPN, Yogyakarta, 2015

Ashshiddiqie, Jimly, Green Constitution: Nuansa Hijau Undang-Undang Dasar Negeri Republik Indonesia Tahun 1945, RajaGrafindo Persada, Jakarta, 2009 
Campbell Black, Henry, Black's Law Dictionary, West Publishing Co, St. Paul, 1979

Elly Erawaty, A.F, Globalisasi Ekonomi dan Perdagangan Bebas: Suatu Pengantar, dalam Susanti Ida, dan Seto Bayu (ed.), Aspek Hukum dari Perdagangan Bebas, Citra Aditya Bakti, Bandung, 2003

Fahrudin, Adi, Kesejahteraan Sosial International, Alfbeta, Bandung, 2012

Hardjasoemantri, Koernadi, Hukum Tata Lingkungan, Gadjah Mada University Press, Yogyakarta, 1989

Hidayat, Arief dan FX. Adji Samekto, Kajian Kritis Penegakan Hukum Lingkungan di Era Otonomi daerah, Badan Penerbitan Universitas Diponegoro (UNDIP), Semarang, 2007

Konoras, Abdurrahman, Aspek Hukum Otoritas Jasa Keuangan (OJK): Teori dan Praktek di Indonesia, Pustaka Pena Press, Makassar, 2015

Konoras, Isyana Kurniasari, Kajian Huku dan Hak Asasi Manusia Terhadap Anak Di Luar Nikah, Tesis Program Pasca Sarjana Universitas Sam Ratulangi, Manado, 2013

Kusumaatmadja, Mochtar, KonsepKonsep Hukum Dalam Pembangunan, Alumni, Bandung, 2006

Lestari Rahayu, Sri, Bantuan Sosial di Indonesia. Sekarang dan Ke Depan, Fokusmedia, Jakarta, 2012
Rachbini, Didiek J, Risiko Pembangunan yang Dibimbing Utang, Gramedia Widiasarana Indonesia, Jakarta, 1995

Rofiq, Aunur, Pertumbuhan Ekonomi dan Kemiskinan. Kebijakan dan Tantangan Masa Depan, Penerbit Republika, Jakarta, 2014

Rusli, Said, Pengantar Ilmu Kependudukan, (Edisi Revisi), LP3ES, Jakarta, 2012

Savitri, Niken, HAM Perempuan. Kritik Teori Hukum Feminis terhadap KUHP, Refika Aditama, Bandung, 2008

Soekartawi, Pembangunan Pertanian untuk Mengentas Kemiskinan, UI Press, Jakarta, 1996

Soemarwoto, Otto, Analisis Dampak Lingkungan, Gadjah Mada University Press, Yogyakarta, 1991

-, Indonesia Dalam Kancah Isu Lingkungan (Global), Gramedia Pustaka Utama, Jakarta, 1992

Sucipto, Yenni, dkk, APBN Konstitusional. Prinsip dan Pilihan Kebijakan, GalangPress, Yogyakarta, 2014

Suharto, Edi, Kebijakan Sosial sebagai Kebijakan Publik, Alfabeta, Bandung, 2008

Sumardi, Mulyanto dan Dieter Evers, Haas (ed.), Kemiskinan dan Kebutuhan Pokok, Rajawali, Jakarta, 1985

Zuhro, Siti, Kisruh Peraturan Daerah: Mengurai Masalah dan Solusinya, Penerbit Ombak, Yogyakarta, 2010 